\title{
Adult Education and International Organizations (UNESCO): Contemporary Policies and Strategies
}

\author{
George Panagiotopoulos \\ Technological Educational Institution of Western Greece \\ Megalou Alexandrou 1, Patras, 26334, Greece \\ Tel: 30- 697-266- 3858 E-mail: gpanag65@gmail.com \\ Katerina Pertesi \\ Technological Educational Institution of Western Greece \\ Megalou Alexandrou 1, Patras, 26334, Greece
}

Tel: 30- 697- 306- 0617 E-mail: katerina.pert@hotmail.com

Zoe Karanikola (Corresponding Author)

Technological Educational Institution of Western Greece

Megalou Alexandrou 1, Patras, 26334, Greece

Tel: 30- 694- 997- 3053 E-mail: zoekaranikola3@gmail.com

Received: August 29, 2018 Accepted: September 10, 2018 Published: September 19, 2018

doi:10.5296/ijld.v8i3.13670 URL: https://doi.org/10.5296/ijld.v8i3.13670

\begin{abstract}
In a rapidly changing world with its diverse spectrum of social characteristics that are currently defining our present period, its continual influx of migrating populations, the growing development of technology as well as the continual increasing rate of unemployment makes it more now than ever, necessary to develop not only international but also national policies that aim to support the viability and advancement of its citizens. International organizations constitute the corner stone of public policy for the confrontation of these challenges. More specifically, UNESCO and the institutions of the European Union (EU) should be called on to play a decisive role in the implementation of Agenda 2030 using the
\end{abstract}


experience and the extended diplomatic networks that they possess. Consequently, important official texts of international policies concerning the prosperity of its citizens through adult education have been recorded. This research, through the qualitative analysis of the UNESCO (2016) text, is meant to highlight and study the dimensions of adult learning and how they can be made applicable. Through the analysis of the text, there are emerging thematic networks, which are related to policy making, a feature of which is the investment in lifelong learning, to disseminate good practices and to evaluate them. A cornerstone of policies, actions and decisions is also the social right of adult citizens.

Keywords: Adult education, international organizations, policy, social rights

\section{Theoretical Underpinning}

\subsection{The Content of Adult Education}

In a time of constant socio-economic changes and swift scientific advances human development is vital. Adult education leads to economic and social transformation, it creates an increase in the number of choices and it is related to problem-solving in everyday life (Escrigas, 2008). More and more emphasis is placed on human skills and abilities, where the involvement of adults in matters that confront them on a daily basis, as well as the existing learning opportunities lead them to greater personal, social and professional recognition (Human Development Report, 2016).

Opportunities in general, affect human activity at both the personal and collective levels. These are structured by the individual's preferences, abilities, cognitive and social norms, the value system, the development and the mechanics it fosters. These in turn can ensure that a fair solution to the conflicts that occur can be dealt with.

Over the last decades adult education has evolved at a rapid pace as a consequence of financial, technological, social and cultural changes and makes it essential for adults to have multiple knowledge and skills that are adapted to their environment (Osterhamme \& Petersson, 2013). The maximization of competition and the internationalization of economy, demands new organization of labor with the exploitation of human resources (Jarvis, 2005). Generally, it is necessary for every adult, in every phase of their lives, to have access to new knowledge and skills that would make it easier for them to integrate in society in order to adapt to alternating conditions and to define themselves (UNESCO, 2015b).

However, according to many Member States, funding, as a response to the implementation of such formal education is limited. This signifies a reduction in the capacity of formal educational institutions to address modern challenges, thus educational institutions are unable to face contemporary challenges and only the flexibility of adult education can help (Day, 2003).

The necessity for high quality human resources able to act autonomously and the application of skills in combination with the use of modern technological tools has stimulated new practices in order to enhance human dexterities. Access to educational activity and learning opportunities contribute to moral conscience, promotion of equality, maintenance of social 
cohesion, mutual respect, creation of viable prosperity as well as economic development in all sectors (Kearns, 2015; Longworth, 2012; Geuvara \& Yorozu, 2015).

\subsection{International Organizations and Development}

As the context of education is rapidly changing, the interest of transnational organizations, like UNESCO and the EU, on educational issues was drawn to adult education from early on. The changes in principles and qualifications that were to affect the professional identity of adults over the next decades have been taken into consideration since the 1970s (Commission of the E.C., 2000; Coolahan, 2002). The work of these international organizations has contributed greatly to the positive outcome of endorsed reforms in national educational systems.

For UNESCO in particular, the greatest contemporary challenge facing international education is to meet the deficit in human resources and to improve the quality of education services. It therefore seeks to contribute to the strategic planning of educational policies in order to tackle them (UNESCO, 2015c). These policies place the adult at the core of development and promote the full advancement of human persona in a climate of mutual respect for basic freedoms (Beech, 2009).

Since the 1930s, UNESCO has pointed out at the International Bureau of Education (www.ibe.unesco.org, 1935) that the educational system should be pedagogically whole, so that it contributes to further professional development. In the Recommendation on the status of adults (UNESCO, 1966) and in subsequent statements, it analyzes the professional profile of the adult, it points out their academic freedom and the need for specific knowledge and skills, while stressing the necessity to create an extensive educational system and salary adjustments according to the social recognition that derives from their labour (UNESCO, 2003; Robertson, 2012a). The 2000 Dakar Forum reiterates the need to improve the status of adults, who should have the respect of the state by participating in the decisions that influence their professional career. At the same time, appropriate strategies are sought in order to encourage adults to remain in the education system for the acquisition of higher qualifications (Tsaousis, 2007).

This is perpetuated by one of the most important actions undertaken by UNESCO concerning education in its participation in the program "Education for all (2012-2015)", where by national governments are called upon to reinforce the morale and professional status of adults, allowing them to be actively involved in educational networks and activities (UNESCO, 2012 $\&$ 2015a). In addition, in the Strategy that was developed for the period 2014-2021, the organization expressed deep concern about the serious qualitative inadequacy that human resources displayed with regards to their level of education and their work. Thus, highlighting the need for the professional development of adults, educational evaluation, the dispersion of reliable methods, the use of new technologies, etc., as necessary tools in order to improve education (UNESCO, 2015b).

Finally, UNESCO has mapped out appropriate strategies for the development of individuals and societies in the context of global collaboration and the prosperity of its member states. It 
is composed of official texts based on international research data, interpreting political strategies and developing evaluation and control mechanisms on forthcoming programs and their corresponding actions (European Commission, 2016). The last text of the "Third Global Report on Adult Learning and Education" (UNESCO, 2016) outlines the findings of a global survey in which 139 member-states of UNESCO participated and examined the influence of Adult Learning and Education on employment and the job market, the state, society, the community, health and prosperity in general. The path of development lies in the corresponding strategies in the form of provided educational programs, in the type of skills each citizen is obligated to possess, and more specifically, as the pillar of social values and rights, fields that constitute a beneficial dimension for the advancement of the individual.

\section{Methodology of Research}

\subsection{Research Objective Research Questions}

The fundamental objective of the present research is to investigate the basic dimensions of adult education through the content analysis of the UNESCO, GRALE III (2016) text. The research questions that arise for this study from the international educational framework and the imperatives of the global status are the following:

- What are the characteristics of the policies of adult education and how are they applied?

- How are social rights implemented into adult education?

\subsection{Presentation of Research Material and Methodological Tool}

The questions arising from this research and the designation of the theoretical framework for adult education at the national and at the international level, have determined the methodology of this research. The UNESCO "Third Global Report on Adult Learning and the Education" (GRALE III, 2016) text refers to the implementation of the Belem framework of action, where 144 member-states of UNESCO participated in the 6th International Congress on Adult Learning and Education in Brazil in 2009. The results of this research relate to and refer to the undertakings of the world's community to achieve the objectives outlined by Agenda 2030. This research explores and analyzes the latest developments that concern adult education, stresses the good policies and methods, and supports the governments of member states so that they can evaluate and redefine their objectives.

In this research we applied qualitative analysis and more specifically we used the methodological tool of thematic analysis through thematic networks. The qualitative analysis is an inductive analytical procedure and is based on the principles of Toulmin's argumentation theory (1958), as is mentioned in Attride-Stirling (2001). Its main objective is to present data in an analytical and compound way, to interpret and to comprehend the various dimensions of the subject and not to solve conflicting approaches (Boyatzis, 1998).

The qualitative research through the thematic analysis is a methodical and systematic analysis of the research material that helps the organization of analysis and allows, not only an extensive exploration of the surface, but also the deeper structures of the text. The 


\section{Macrothink}

development of qualitative methods is a result of the acceptance of the explanatory model that shows the general picture and the prevailing trends, while at the same time it is a form of coding qualitative data (Clarke, Braun, \& Hayfield, 2015). More specifically, the method of thematic networks includes flexibility, large-scale data, interpretation of subjects based on data and finally classification (Braun \& Clarke, 2006; Gibbs, 2007).

There are three thematic classes: the basic theme, the organizing theme and the global theme. The basic theme is related to the simplest characteristics of the text's data and provides very little information about the whole text on its own. In order to achieve a better and clearer understanding of the text's content, it is essential to study the other key issues further. All together, they constitute the second class of themes, and more specifically, the organizing theme. This is a middle-order theme, which organizes the main topics in categories of "related" subjects. This particular theme contributes to a better understanding of a more general theme, which connects several organizational issues. Thus, the third theme, the Global Theme, emerges as a super-ordinate theme which contains the basic idea of the text as a whole (Attride-Stirling, 2001).

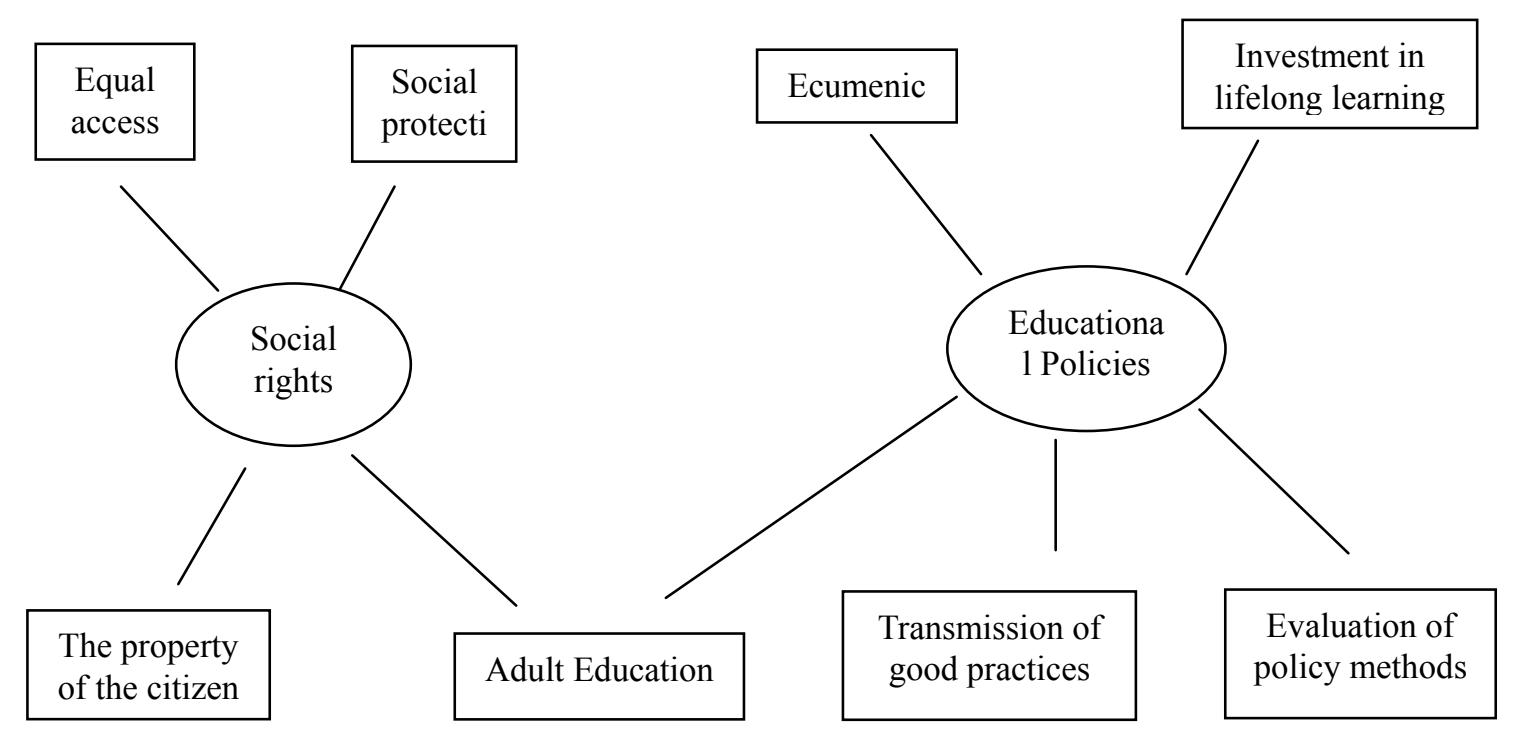

Figure 1. Structure of a thematic network

\subsection{Creation and Description of Thematic Networks}

The main theme of this research is adult education. The organizing themes that arose from the analysis of the text are: policies of development of adult education and social rights, which are necessary for the development of adult education policies.

More specifically, the first thematic network is related to the policies that support adult education and are characterized by ecumenism, inclusion and a united political approach of all member-states (UNESCO Institute for Lifelong Learning, 2010). The political actions should be considered part of a wider sociopolitical and economic field so that there is 
development for adults and consequently societies. The framework of viable development, as mentioned in the 2030 Agenda, expresses the necessity of international strategic planning that will encourage and support the complementarity of all factors of development. These include education, employment, the job market, the state, society, health and more generally prosperity (European Parliament, 2016). Development depends on corresponding strategies, the form of provided education and the type of skills that each adult should have (UNESCO Institute for Lifelong Learning, 2016).

According to UNESCO (GRALE III, 2016: 32) the ecumenical political approach should include three fundamental axes in order to be effective:

- Adult education as an integral part of lifelong learning in the framework of support and encouragement of a democratic political system.

- The impact of national policies for adult education as a long-term approach, with frequent progressive evaluation and inclusion of political frameworks.

- Diagnostic evaluation of national policies not only of the requirements of the job market but also of personal and social needs.

The countries participating in the research provided reports on the improvement of policies of adult education and the establishment of a new political framework which recognizes and ratifies the informal forms of education in comparison with the research conducted in 2009 (Yang, 2015). Its results showed that actually $75 \%$ of the 128 participating countries had progressed significantly in this sector. More specifically, $70 \%$ of them established new policies of approach in adult education and introduced a framework for informal learning. The adoption of educational strategies for the effective connection between formal and informal education in Greece, Mali and Georgia are typical examples. The law 4186/2013 in Greece for the recognition of certificates of informal education by private and public institutions at national level is proof of this (UNESCO, 2016: 32-33).

One of the most important international policies, apart from the coherent and coordinated strategy, is the investment in lifelong learning. The percentage of public funding with regards to adult education is disappointing as it remains quite low in the investment priorities of governments and international organizations, whose priority lies with health, building infrastructure and social welfare depending on the structural characteristics of each state. More specifically, the low percentage of public spending (about 2,2\%) that was allocated to adult education in 2009 (GRALE II, 2009) increased gradually, according to the next research of UNESCO (GRALE III, 2016). At least more than half of the countries (57\%) declared that there was need for redefined planning with regards to the increase of investments in adult education, while $48 \%$ of the states reported remarkable innovations in funding comparatively with the year 2009. This is encouraging for the achievement of the objectives of sustainable development in 2030 (GRALE III, 2016: 48).

As a consequence of the global economic crisis in 2008-2009, the giant economic forces of the European Union, the United States and China were coerced into reducing their financial resources and as a result, adult education suffered since it had to compete against other 
investment priorities. Subsequently, the lack of co-ordination amongst the government departments with regards to the internal management of resources created problems in the efficient allocation and mobilization of government spending, as well as the absence of initiatives by the relevant bodies (UNESCO, 2016: 45).

However, in order to understand the real value of investing in adult education, all countries should be obliged to use specific indicators to measure the resources that "are introduced" into the educational system. Thus, the results that are on the receiving end should precipitate into qualifications and skills. In this way, we can observe the development of human resources in each state and consequently the added value at both the economic and political levels.

Furthermore, it is recommended that collaboration between member-states and the exchange of good practices and teaching methods is needed for an effective policy to be executed. Governmental organizations, research institutions, civil services, trade unions and other establishments that promote adult education through programs and agendas aid at this attempt. When disseminating ideas, particular attention should be paid to the conditions and the characteristics of the individual countries, so that they adopt elements that suit the structures, methods and the techniques of their education. By applying this approach, effective international collaboration of all member-states is ensured despite their stage of development (UNESCO, 2016).

The exchange of ideas and practices is not only beneficial between states at a global level but also between local and regional authorities at a national level. Governments, in collaboration with the Region's services, extend their policies to reinforce the mechanisms of adult learning and education. Moreover, the quality of the educational framework is evaluated according to the conveyance of ideas and the transfer of responsibilities, in particular from the lower levels to the higher levels of the educational pyramid (bottom to up), which promotes professional development (UNESCO, 2016).

The transmission of good practices is achieved through the mobility of adults and their participation in various active programs, whose primary objective is, among others, education. Such programs that have been implemented in the last decades are ARION, Comenius, Grundtvig, Erasmus and Erasmus plus (UNESCO, 2016). It is through these that adults have acquired access to new informative systems, technological applications and communication as well as other modern technologies.

The evaluation of policy methods by the engravers of educational strategies is an integral part of adult education. Educational policy makers (like Ministries, private institutions, local authorities, international and regional organizations) are called upon to modernize their policies according to the requirements outlined by the economic, political, social, cultural and technological environment. In addition, they are obliged to check and evaluate the application of educational methods and techniques that are developed, so that they are flexible enough to meet the future needs, issues and challenges that materialize in the educational "sphere". In order for this to be feasible, a single network of operation and distribution of resources is required that is flexible, quick and decentralized, ensuring the response to the requirements of 
the modern world (Schuller \& Watson, 2009).

Adult education constitutes a multidimensional and complex field of policy that interacts and contributes to other sectors of policy action. However, the responsibility for adult education is divided into many public services (like education, immigration) and ministries (like the Ministry of Education) but also at various policy levels (national, regional, local). This unclear separation of responsibilities by the bodies and structures of education, the lack of co-ordination and the differing approaches of political parties, contribute to the fragmentation and the inefficiency of evaluation in the field of adult education (Desjardins, 2017). Through this process, not only the benefits but also the deficiencies of policy directions that were followed are depicted with the primary objective of reconstructing them in order to achieve higher cost savings.

Effective policy recommends collaboration between many sectors of policy action (like education, the job market and health), the social partners and civil society. It is particularly important to use effective strategies of approach to encourage participation of adults in the educational sector and later in the sociopolitical framework. Member-States worldwide must ensure a long-term strategic vision which is adequately flexible and responds to new challenges that the international system poses without proceeding to fragmentary and incohesive moves (UNESCO, 2016: 32).

The second thematic network is associated with the integration of social rights in adult education. Social rights are related to the support of equal access to the educational process, civic protection and the assets of the individual.

According to global development, social rights are considered to be a compass for the improvement and the evolution of individuals and more generally, society. This is why they are included in the educational process of adults. They must be able to influence the shaping of social values and norms (Institute for Lifelong Learning \& UNESCO, 2013).

Attendance, inclusion and equality are the backbone of the formation and constitutional provisions of all member-states. The promotion of social integration is vital so that no adult, as a member of society, is excluded from the programs of lifelong learning and adult education. All adults are entitled to equal access to education and opportunities regardless of their cultural, linguistic and economic state, through integrated strategies of inclusion. In this way, their motives for learning are enhanced, their needs are reconnoitered and all categories of discrimination are eliminated. The investigation ensues through learning approaches, that bear in mind the diversity of adults (such as their cultural heritage, values), allow the formation of communication bridges between different groups that reinforce their integration within the learning communities (UNESCO, 2016).

Adult education constitutes a motivating force for social protection. This is achieved through respect in heterogeneity, the empowerment of all adult groups, solidarity and social justice, elements which constitute part of the principles of policy action within the international and European framework. According to studies, the development of the educational level, the support of practical and digital skills, the assumption of social and political responsibilities 
and the cultural comprehension of heterogeneity promote learning communities, which are related to the achievement of the objectives set out by the 2030 Agenda (UNESCO, 2016).

Adult education also includes educational opportunities for the active execution of the citizen's duties. Through this role, adults participate actively in social matters that deal with the "social world", like social mobility, employment, poverty, unemployment, the job market, social cohesion, social exclusion and programs of environmental protection. The constant cultivation of lifelong learning contributes to the minimization of obstacles for the participation in public matters and the encouragement in decision-making (UNESCO, 2015a).

According to the declaration of Hamburg, at the 5th International Conference, it was pointed out that "adult education is the consequence of the active citizen and condition for their full involvement in society" (UNESCO Institute for Education, 1997). Member-states that provide high quality adult education have higher rates of socio-economic development, active participation in political activities and social integration. However, in countries where inequality of power and wealth prevails, the field of adult education appears pretentious and at the same time, impaired (Organization for Economic Co-operation and Development, 2014).

Finally, social values and rights remain fundamental to the achievement of the objectives that Agenda 2030 sets for viable development, both socially and educationally. Governments and international institutions focus on visible results and measurable goals and this is a fact that is not directly apparent in the sector of adult education. However, according to the international framework, they invest in this and its profits are reflected in the social protection, confidence and cohesion in the long run (UNESCO Institute for Lifelong Learning, 2010).

\section{Discussion on the Results}

The research results, which emerged through the content analysis revealed multiple dimensions of adult education, which are allocated in smaller parts. A basic dimension of adult education is the mapping out and the application of ecumenical, inclusive policies, in agreement with the particular characteristics and structures of education by each member-state. In this way, international comprehensiveness and coherent political action is achieved (OECD, 2013). International organizations collaborate with each other and their policies are complementary and interrelated. More specifically, the adaptation of international strategies should be integrated according to ideological issues, historical background, administrative models, educational practices, educational needs as well as the social models and values of each country (Eurydice, 2002; European Commission, 2011; Reder, 2012; Eurydice, 2015).

Investment in lifelong learning is constantly included in the policy making process, which is demanded not only by European governing bodies, but also by all international ones, too. Learning methods, which are based on the principles of adult education, can improve the professional profile of adults, enhance innovation and the quality of the existing educational process, so that adults can actively participate in the labour market so as to be continuously attracted to the educational program. Adults taking part in the lifelong learning experience 
have more accessibility to the employment sector and are able to reap the benefits of the "status quo" by becoming more active citizens in the socio-economic framework (Wolf \& Evans, 2011). The exchange of good practices also institutes as an effective educational policy for the international framework, since through the mobility of adults, international organizations can convey effective learning methods, adopt them according to their particular characteristics and positively influence the economy of their country at a national and a European level (Robertson, 2012; European Commission, 2013).

Such an undertaking involves the evaluation of policy methods that operate by receiving feedback from the educational policy designers, since they have to know the point from which they began, where they have arrived and to what extend they have improved with regards to the practices of adult education. Such an example is the action by the ET 2020 group, who through a specific framework, recorded the policies that were followed by the competent authorities of the member-states (European Commission, 2015: 4; Carpentieri, 2015).

The second dimension of adult education is related to the integration of social rights in the educational process. More specifically, equal access to the learning process, social protection and the civil rights of the individual, appear to adequately address the diversity of the educational needs and the elimination of social discriminations so that human rights are protected (Baynham et al., 2007). Social cohesion is a major policy issue, especially in times of socio-economic crisis, where resources and employment opportunities have been greatly condensed. Internal mobility and the active migration of people has generated the need for inclusion and equal integration of adults in education and more so in the job market (European Commission, 2011). Hence, despite the fact that the social world of the member-states is multifaceted, with differing dimensions, it is essential that emphasis be placed on social justice, social dialogue and the collaboration of its members (Institute for Lifelong Learning \& UNESCO, 2013).

It should be pointed out that this research is constrained to the exploration of a means to develop and expand the dimensions of adult education, as it appears from the content analysis of the international UNESCO (2016) text. However, certain questions arise regarding the practical implementation of the methods outlined by the international framework. Will the objectives of Agenda 2030 be included in the policies of member-states and, if so, to what extent? Have the outlines set out for adult education been applied adequately, as pointed out in the text? Since UNESCO frequently mentions the necessity for cohesion, collaboration of policies and the exchange of good practices among member-states, why then are vulnerable groups of people (unskilled adults) still outside the educational framework and other groups of adults continue to be favored (Cedefop, 2016)? Thus, the issue of policy transfer and its application from official documents is brought to the forefront.

In the future, research into this would be beneficial, so as to scrutinize which of the processes are being harnessed and how all theoretical policies are being incorporated by international organizations regarding the development of adult education. 


\section{Macrothink}

\section{References}

Attride-Stirling, J. (2001). Thematic Networks: an Analytic Tool for Qualitative Research. Qualitative Research Copyright, $\quad I \quad$ (3), 385-405. https://doi.org/10.1177/146879410100100307

Baynham, M., Roberts, C., Cooke, M., Simpson, J., Ananiadou, K., Callaghan, J., \& Wallace, C. (2007). Effective teaching and learning: ESOL. London: NRDC.

Beech, J. (2009). Who is strolling through the global garden? International agencies and educational transfer. In: Cowen, R., \& Kazamias, A. M. (Eds.). International handbook of comparative education (pp. 341-357). Dordrecht: Springer. https://doi.org/10.1007/978-1-4020-6403-6_22

Boyatzis, R. E. (1998). Transforming Qualitative Information: Thematic Analysis and Code Development. London \& New Delhi: Thousand Oaks, SAGE Publications.

Braun, V., \& Clarke, V. (2006). Using thematic analysis in psychology. Qualitative Research in Psychology, 3, 77-101. https://doi.org/10.1191/1478088706qp063oa

Carpentieri, J. (2015). Adding new numbers to the policy narrative: Using PIAAC data to focus on literacy practices. In M. Hamilton, B. Maddox and C. Addey, (eds.). Literacy as Numbers. Cambridge: Cambridge University Press.

Cedefop, European Commission (2016, forthcoming). Update to the European inventory on validation of non-formal and informal learning: synthesis report.

Clarke, V., Braun, V., \& Hayfield, N. (2015). Thematic analysis. In J. Smith (Ed.). Qualitative psychology: A practical guide to research methods (3rd ed.) (pp. 222-248). London: Sage.

Commission of the Europeans Communities/Commission Staff Working Paper. (2000). A Memorandum on Lifelong Learning. SEC. Brussels.

Coolahan, J. (2002). Teacher Education and the Teaching Career in an era of Life Long Learning. OECD Education Working Papers, no.2, OECD: Publishing. Retrieved from: http://doi.org/10.1787/226408628504

Day, C. (2003). The development of teachers. Athens: Typothito.

Desjardins, R. (2017, forthcoming). The Political Economy of Adult Learning Systems: Alternative Strategies, Policies and Coordination of Constraints. London: Bloomsbury.

Escrigas, C. (2008). Forward in GUNI. Higher Education in the World 3. London: Palgrave Mcmillan.

European Commission. (2011). Demography report 2010: Older, more numerous and diverse Europeans. Commission Staff Working Document.

European Commission. (2013). The Survey of Adult Skills (PIAAC): Implications for education and training policies in Europe. DG-EAC. 


\section{Macrothink}

International Journal of Learning and Development

ISSN 2164-4063 2018, Vol. 8, No. 3

European Commission. (2016). Proposals for a new European Consensus on Development. Our World, our Dignity, our Future. Strasburg, 22/11/2016. Retrieved from: https://ec.europa.eu/europeaid/new-european-consensus-development-our-world-our-dignityour-future_en

European Parliament. (2016). Report on 2016 Discharge - European Parliament Rapporteur: Derek Vaughan. Retrieved from: http://www.europarl.europa.eu/cmsdata/140720/EP_A8-0105_2018_EN.pdf

Eurydice. (2002). Initial training and transition to working life. Volume 1, The teaching profession in Europe: Profile, trends and concerns. General lower secondary education. Brussels: Eurydice.

Eurydice. (2015). Adult Education and Training in Europe: Widening Access to Learning Opportunities - Eurydice Report. Luxembourg: Publications Office of the European Union.

Gibbs, G. R. (2007). Thematic Coding and Categorizing. Analyzing Qualitative Data. London: SAGE Publications, Ltd.

Human Development Report. (2016). Human Development for Everyone. New York.

Institute for Lifelong Learning \& Unesco. (2013). 2nd Global report on adult learning and education (Repr. with minor rev. ed.). Hamburg: UNESCO Inst. for Lifelong Learning, p. 48.

Jarvis, F. (2005). Founders the education of adults. Athens: Verge.

Kearns, P. (2015). Learning cities on the move. Australian Journal of Adult Learning, 55 (1).

Longworth, N. (2012). Learning Cities and Learning Regions: Helping to make the world a better place. In D. Aspin, J. Chapman, K. Evans \& R. Bagnall (eds), Second International Handbook on Lifelong Learning. Heidelberg: Springer. https://doi.org/10.1007/978-94-007-2360-3_41

Noguchi, F., Geuvara, J., \& Yorozu, R. (2015). Communities in Action: Lifelong Learning for Sustainable Development. Hamburg: UNESCO Institute for Lifelong Learning.

OECD. (2013). OECD Skills Outlook 2013: First results from the Survey of Adult Skills. Paris: Organisation for Economic Cooperation and Development. Retrieved from: http://skills.oecd.org/OECD_Skills_Outlook_2013.pdf

Organisation for Economic Co-operation and Development. (2014). Education at a Glance 2014: OECD indicators. Paris.

Osterhammel, J., \& Petersson, N. P. (2013). Globalization: A Short History. Translated by Dona Geyer. Princeton: Princeton University Press 2005.

Reder, S. (2012). The Longitudinal Study of Adult Learning: Challenging assumptions. Montreal: Centre for Literacy.

Robertson, S. L. (2012). Placing teachers in global governance agendas. Comparative Education Review, 56 (4), 584-607. https://doi.org/10.1086/667414 
Schuller, T., \& Watson, D. (2009). Learning through life: inquiry into the future of lifelong learning. Leicester, NIACE.

Tsaousis, D. (2007). The educational policy of International Organisms. World and European dimensions. Athens: Gutenberg.

UNESCO. (1966). Recommendation concerning the Status of Teachers. Paris: UNESCO.

UNESCO. (2003). Building Capacity of Teachers/Facilitators in Technology - Pedagogy Intergration for Improved Teaching and Learning. Final Report: Experts Meeting. Bangkong: UNESCO.

UNESCO. (2012). Youth and skills: Putting education to work. Paris: UNESCO.

UNESCO. (2015a). Global Monitoring Report: Education for All 2000-2015: Achievements and Challenges. Paris: UNESCO.

UNESCO. (2015b). Education Strategy 2014 - 2021. Paris: UNESCO.

UNESCO. (2015c). Recommendation on Adult Learning and Education (2015). Paris. Retrieved from: http://unesdoc.unesco.org/images/0024/002451/245119M.pdf

UNESCO Institute for Education. (1997). Adult Education: The Hamburg Declaration; the Agenda for the Future. Hamburg: UNESCO Institute for Education. Retrieved from: http://unesdoc.unesco.org/images/0011/001161/116114eo.pdf

UNESCO Institute for Lifelong Learning. (2010). Global Report on Adult Learning and Education. Hamburg. Available: http://unesdoc.unesco.org/images/0018/001864/186431e.pdf

UNESCO Institute for Lifelong Learning. (2010). Belém Framework for Action. Hamburg, UNESCO Institute for Lifelong Learning. Retrieved from: http://unesdoc.unesco.org/images/0018/001877/187789m.pdf

UNESCO Institute for Lifelong Learning / European Training Foundation / Centre Europeen pour le developpement de la formation professionelle. (2015). Global Inventory of Regional and National Qualifications Frameworks, I, II. Hamburg: UNESCO Institute for Lifelong Learning. Retrieved from: http://unesdoc.unesco.org/images/0023/002330/233043E.pdf

UNESCO Institute for Lifelong Learning. (2016). Collection of Lifelong Learning Policies and Strategies. Hamburg: UNESCO Institute for Lifelong Learning. Retrieved from: http://uil.unesco.org/lifelong-learning/lifelong-learning-policy

analysis/collectionlifelonglearning-policies-and

UNESCO. (GRALE III, 2016). $3^{\text {rd }}$ Global Report on Adult Learning and Education. The Impact of Adult Learning and Education on Health and Well-Being; Employment and the Labour Market; and Social, Civic and Community Life. Hamburg: UNESCO Institute for Lifelong Learning.

Wolf, A., \& Evans, K. (2011). Improving literacy at work. London: Routledge.

Yang, J. (2015). Recognition, Validation and Accreditation of Non-formal and Informal 


\section{Macrothink}

International Journal of Learning and Development

ISSN 2164-4063 2018, Vol. 8, No. 3

Learning in UNESCO Member States. Hamburg: UNESCO Institute for Lifelong Learning.

\section{Copyright Disclaimer}

Copyright for this article is retained by the author(s), with first publication rights granted to the journal.

This is an open-access article distributed under the terms and conditions of the Creative Commons Attribution license (http://creativecommons.org/licenses/by/4.0/). 